\title{
Review of Chinese and Foreign Management Accounting Research-Based on Management Accounting Research Topics and Research Methods
}

\author{
Jie Xie \\ School of Management, Jinan University, Guangzhou, China \\ Email: sunnygir1912@163.com
}

How to cite this paper: Xie, J. (2019) Review of Chinese and Foreign Management Accounting Research-Based on Management Accounting Research Topics and Research Methods. Open Journal of Social Sciences, 7, 107-119.

https://doi.org/10.4236/jss.2019.712009

Received: November 11, 2019

Accepted: December 3, 2019

Published: December 6, 2019

Copyright $\odot 2019$ by author(s) and Scientific Research Publishing Inc. This work is licensed under the Creative Commons Attribution International License (CC BY 4.0).

http://creativecommons.org/licenses/by/4.0/

\section{(c) (i) Open Access}

\begin{abstract}
This paper takes 71 management accounting documents published in the 2015-2017 mainstream journals as a sample, systematically combs, summarizes and reviews the management accounting research topics and research methods. We find that the subject of management accounting research is increasingly diversified, with performance evaluation and measurement, compensation and incentive research being the most popular. There are obvious differences in research methods at home and abroad. Among them, domestic research mainly focuses on data-based empirical analysis and normative research, while foreign literature research methods prefer experimental research methods. I hope that the comparative analysis of the article can provide reference for the research and development of domestic management accounting.
\end{abstract}

\section{Keywords}

Management Accounting, Research Topic, Research Method, Management Control System

\section{Introduction}

In 2014, the Ministry of Finance issued the guidance of the Ministry of Finance on comprehensively promoting the construction of management accounting system (Draft for comments), which is the first time in China to comprehensively promote the construction of management accounting system in China, and specifically explained the objectives, main tasks and measures of management accounting system. In 2016, the Ministry of Finance officially launched the 
basic guidelines for management accounting to promote the work of management accounting, improve the level of internal management, and promote economic transformation and upgrading. In order to respond to the call of the state and promote the development of management accounting in China, a lot of research has been carried out in theory and practice.

However, there are few systematic summary studies on the research topics and methods of management accounting in our country, and there are the following defects: first, the research interval fails to reflect the latest development of management accounting, which makes the conclusions out of touch with the practical guiding significance; second, the research object is not comprehensive enough, most of them only consider the development of domestic management accounting research, ignoring to sort out the related documents of foreign management accounting research, so that we cannot know the hot research topics and research methods, it is difficult to provide reference for domestic scholars.

In view of the shortcomings of the existing research, this paper reviews the research literature of management accounting in the mainstream academic journals at home and abroad from 2015 to 2017, systematically summarizes the theme and research methods of management accounting research, hoping to provide direction for further research of management accounting.

\section{The Research Sample}

In view of the authority and influence of journals, this paper does not cover the journals other than accounting and with insufficient influence factors. Chinese journals mainly selected "Management World", "Economic Research", and "Accounting Research". English journals ranked according to the "Social Science Citation Index" (SSCI) impact factor ranking, and selected five top accounting journals (Management Accounting belongs to the sub-areas of these five journal studies). However, because Accounting and Economics (JAE) has not covered management accounting articles in the past three years, the Journal of Accounting Research (JAR) and Accounting Review (AR) have fewer management accounting articles, and at last, the English journals mainly choose Accounting, Organization and Society (AOS) as the research object. By selecting the above journals as the analysis object, it can reflect the status quo and development prospects of mainstream management accounting research at home and abroad. The selection time of the paper is from 2015 to 2017. According to the above criteria, after the statistics, the paper finally selected 71 papers. The specific distribution of these papers in the journal is shown in Table 1.

From Table 1, it can be seen that there are many articles on management accounting research in "Accounting Research" in recent three years, accounting for $45.1 \%$ of the samples selected; 16 articles on "Management World", accounting for 22.5\%; few studies on management accounting theme in "Economic Research", only one in recent three years. In the foreign literature, "Accounting, Organization and Society" has made great contribution to the research of management accounting, with 22 articles in recent three years. 
Table 1. Journal distribution.

\begin{tabular}{cc}
\hline Journal & $2015-2017$ \\
\cline { 2 - 2 } & Number Of Articles (\%) \\
\hline Management World & $16(22.5)$ \\
Economic Research & $1(1.4)$ \\
Accounting Research & $32(45.1)$ \\
Accounting, Organization and Society/AOS & $22(31.0)$ \\
Total & $71(100.0)$ \\
\hline
\end{tabular}

Note: The percentages in parentheses.

\section{Management Accounting Research Review}

\subsection{Research Theme}

In order to avoid the research topic being too scattered, 71 articles were classified according to the methods of Shields (1997) [1], Du Rongrui (2009) [2] and Meng Yan (2014) [3]. The problems of management control system can be divided into five categories, which are performance measurement and evaluation, budget (including budget communication, budget management, budget negotiation, etc.), internal control, compensation and incentive, and general management control system. The research of cost problem can be divided into three aspects: cost accounting, cost stickiness (there are many researches on cost stickiness in recent three years, so this topic is listed separately) and other cost problems. External oriented management accounting mainly includes value chain analysis, strategic management and supply chain management. In recent years, supply chain management has attracted more attention. The general problems of management accounting mainly involve general problems and practical investigation. Other issues include value-based management issues and management accounting information systems.

As shown in Table 2, during 2015-2017, there were 38 articles (53.5\%) related to management control system in the journals studied, which are still the key issues of domestic and foreign research, among which performance measurement and evaluation as well as compensation and incentive issues dominate. There are 7 papers $(9.8 \%)$ on cost accounting and management. It can be seen that there are few studies on cost in recent three years. There are 12 papers $(16.8 \%)$ involved in the general research of management accounting. The problems of management accounting itself have been hot in recent years, mainly due to some discussion on the theoretical construction of management accounting framework and the innovation of research methods. External-oriented management accounting 10 papers (14.0\%), supply chain management, which accounted for $5.7 \%$, strategic management accounting accounted for $4.2 \%$, value chain analysis accounted for $2.8 \%$. 4 other topics (5.8\%) that cannot be classified in the above categories. 
Table 2. Study topic distribution.

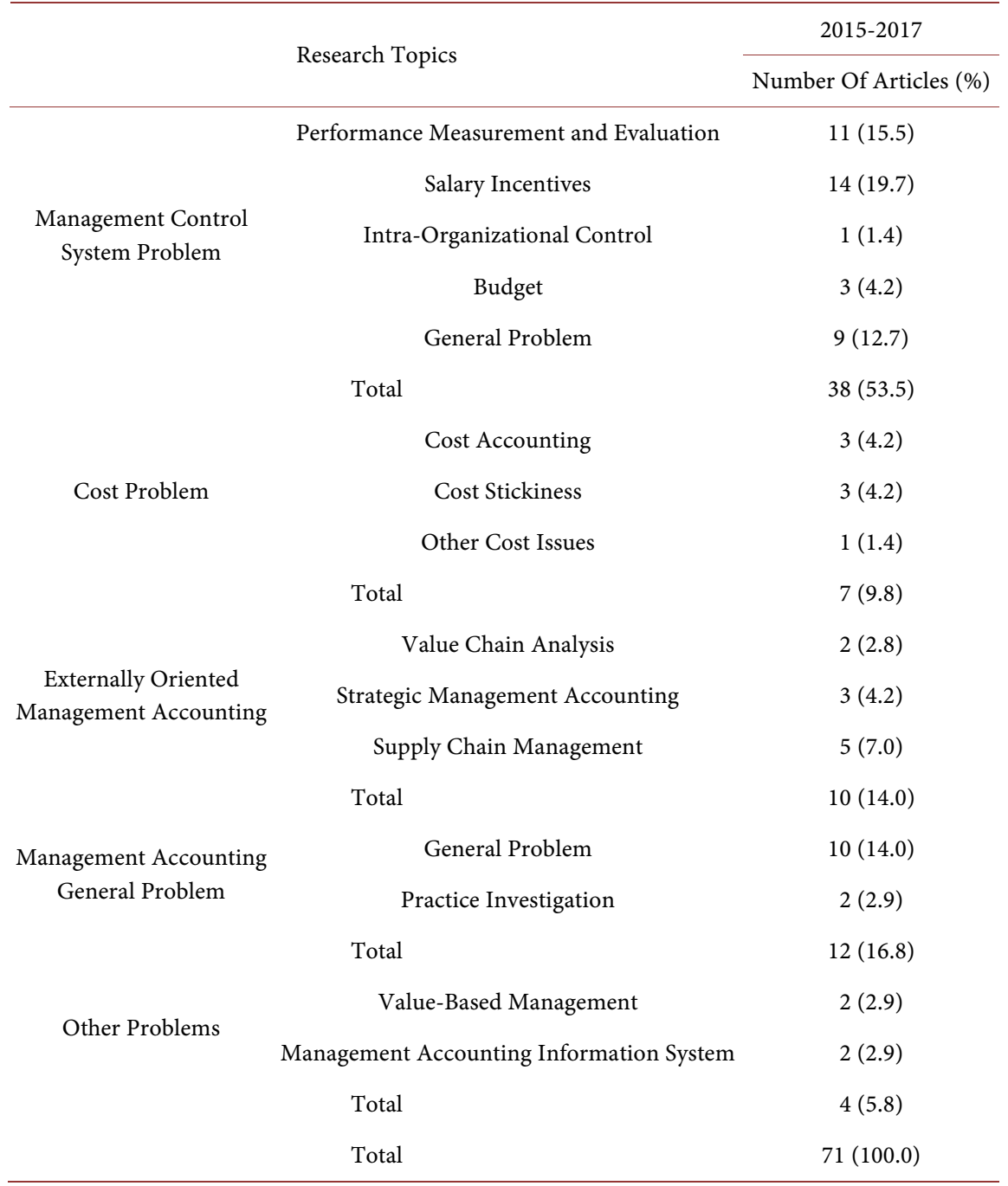

Note: The percentages in parentheses.

\subsubsection{Management Control System}

In 2015-2017, the research on management control system at home and abroad mainly focused on performance measurement and evaluation (11 papers), compensation and incentive (14 papers). In addition, there are many researches on management control system itself, which is defined as general problems of management control system (9 papers).

The research of performance measurement and evaluation in China is mainly aimed at the implementation effect of some enterprise performance evaluation models and the improvement of the original evaluation system. For example, EVA model of risk adjustment and its application in performance evaluation of central enterprises (Zhou Baicheng, Marco Wei, etc., 2016) [4]. In foreign countries, the research focuses on the expression of performance measurement system and the relationship between performance and individual. For example, the expression function of performance measurement system: field research of mental health development project (Robert H. chenhall et al., 2017) [5]; research 
on the relationship between performance and individuals, such as how the time of performance feedback affects individual performance (Todd a. thornock, 2016), which designs performance evaluation and feedback by incorporating the concept that learning cost fluctuates in each stage of multi-step task, the system provides practical significance [6].

The research of compensation system is mainly to explore the related problems of the company's executive compensation, and the related research of executive compensation is mainly based on the prevailing compensation control. At the same time, due to the development of modern enterprise system, the separation of enterprise ownership and management rights, how to reasonably distribute executive compensation, encourage executives to consider more shareholders' interests and enterprise value, in order to reduce agency costs is a hot topic discussed by scholars. The incentive system mainly involves the research on the incentive system and methods of executives and employees, in order to improve the performance of enterprises and create more value. Foreign scholars Margaret A and Abernethy (2017) found that management's organizational identity (OI) can effectively reduce agency costs [7]; Jason L. Brown (2016) found that compensation based on performance can more attract participants with higher skill level and high risk preference [8]. Domestic scholars Chai Cai and Huang Shizhong (2017) studied the relationship between competitive strategy, executive compensation incentive and corporate performance from three perspectives of compensation incentive. The results showed that: when examining the impact of executive compensation incentive on corporate performance, we should select the matching executive compensation incentive mechanism according to different competitive strategies, and pay more attention to the selection of executive incentive methods. Otherwise, it will have a negative impact on the company's performance. This conclusion further explains the phenomenon of "decoupling" between executive compensation and corporate performance in reality and the divergence of research conclusions on executive compensation incentive and corporate performance in academic research, which has certain theoretical and practical significance [9]. Wang Xin and Li Yanlin et al. (2015) studied the effectiveness of corporate social responsibility and manager compensation incentive, and found that social responsibility may become a new agent factor and an excuse to shirk responsibility on camera for managers' compensation incentive in state-owned enterprises, especially when state-owned enterprises are faced with performance decline, social responsibility environment pressure is large, and ownership is scattered, which is more obvious. In private enterprises, this phenomenon does not exist [10].

This paper points out that corporate social responsibility does not necessarily result in the low efficiency of corporate budget soft constraint and manager compensation incentive. In view of the salary assessment of state-owned enterprise managers, we need to focus on the performance assessment of corporate social responsibility. However, the above research on compensation and incentive system adopts more research ideas and methods in the field of corporate 
finance, but the research topic belongs to the research category of management accounting.

In the past three years, only one journal has been selected for the study of internal control, which comes from the Management World. It mainly studies the advantages and disadvantages of internal control from the perspective of budget implementation and budget slack.

Budget mainly focuses on budget negotiation, budget communication and budget management. For example (Markus C. Arnolda, Robert M. Gillenkirch, 2015) negotiated budget for planning and performance evaluation: an experimental study [11]. For example, domestic scholars Liu Lingbing and Han Xiangdong (2015) selected Shenhua Group, a Chinese local enterprise that has implemented budget management for 16 years, and studied the meaning construction mode in the development and evolution of enterprise budget management [12]; Liu Lingbing and Sun Zhen (2016) studied the motivation, form and effect of budget communication based on the empirical evidence of in-depth investigation of Chinese enterprises, and the results suggested that enterprise management in addition to paying attention to the budget process and technical methods, they should also pay attention to the important role of communication, culture, personnel and other factors in improving the budget effect [13].

In this paper, we define the management control system as a general problem. This kind of research mainly includes the following questions: 1) Introduce the application of management control system in enterprises; 2) Study the significance and mechanism of enterprise application management control system, such as the dislocation control of (Evelien Reusen, Kristof Stouthuysen, 2017): the role of management control system imitation in supply chain [14];3) Study the integration of management control system, such as (Robert H Chenhall, Frank Moers, 2015) the role of innovation in the development of management accounting and its integration with management control [15]; 4) The impact of management control system on performance, such as (Jasmijn C. BOL, Stephan Kramer, etc., 2015) how control system design affects performance evaluation compression: the role of information accuracy and result transparency [16].

\subsubsection{Cost}

Cost issues in 2015-2017 include cost accounting, cost stickiness and some other cost issues. Among them, regarding the cost stickiness, such as the implementation of the minimum wage regulations and the Cost Stickiness of enterprises (Jiang Wei, Yao Wentao and Hu Yuming, 2016), taking the implementation of the minimum wage regulations of China in 2004 as the starting point, this paper examines the impact of the increase of employee costs caused by the implementation of the minimum wage regulations on the Cost Stickiness of enterprises in China from a dynamic perspective. The research results show that after the implementation of the minimum wage regulation in 2004, the Cost Stickiness of Chinese enterprises has weakened. Further research finds that in state-owned enterprises, enterprises with low per capita wages of employees, labor-intensive 
industries and regions with low degree of marketization, the implementation of the minimum wage regulation has a stronger weakening effect on the Cost Stickiness [17].

\subsubsection{Externally Oriented Management Accounting}

This kind of research includes three subjects: value chain analysis, strategic management accounting and supply chain management. Research on strategic management, such as (Jia Jianfeng, Tang Guiyao, 2015) research on the impact of the match between executive competency and strategic orientation on corporate performance, enrich and expand the research on the match between executive competency, strategic orientation and corporate performance, which provides theoretical basis and empirical support for understanding and explaining the strategic decision-making of Chinese enterprises [18]; for example (Song Hua, Lu Qiang, 2017) found that the strong connection and weak connection of SMEs in the supply chain network play an important role in improving their ability and financing performance, especially the weak connection is more conducive to the realization of supply chain financing [19].

\subsubsection{Management Accounting General Issues}

Such topics include general questions (10 papers) and management accounting practice (2 papers). In recent three years, the general problems of management accounting are mainly the discussion and innovation of management accounting theory and method, and how to develop management accounting under the change of social environment, to conform to the trend and change of the times. For example, Shen Yifeng and Guo Xiaomei (2015) studied the background, content and influence of CIMA's global management accounting principles [20]; Feng qiaogen (2015) studied the change management and innovation exploration of management accounting [21]; Guan Ruidi and Nan Xingheng (2016) on the innovation and development of management accounting with Chinese characteristics under the new normal [22]. In addition, there are two studies on management accounting practice.

\subsubsection{Other Issues}

The literatures not covered in the above research categories include two topics: management accounting information system (2 papers) and value based management (2 papers). Among them, the research of management accounting information system is mainly about the theoretical revision and integration of the system. The research of value-based management mainly involves EVA enterprise value management.

\subsection{Research Methods}

This paper classifies the research methods of management accounting documents from 2015 to 2017. According to the classification of Du Rongrui et al. (2009) [2], the research methods are divided into six categories: Empirical Research Based on database, normative analysis, experimental research, field re- 
search, case study and analytical model research. It also analyzes the application of research methods from two perspectives: the distribution of research methods in different journals and the distribution of research methods in different topics.

\subsubsection{Distribution of Research Methods in Research Journals}

As shown in Table 3, the distribution of six research methods in Accounting Research, Economic Research, Management World, and Accounting, Organization and Society, from the statistical results, the overall empirical research and normative analysis whose proportion is relatively large, accounting for $32.4 \%$ and $28.2 \%$ of the selected literature, respectively. Analytical model research and case study methods are less used in management accounting, accounting for only $4.2 \%$ and $5.6 \%$ of the study sample. Domestic journals, such as the most widely used research methods in Accounting Research, are also empirical studies and normative analysis studies. The research methods used in management accounting articles in Management World mainly focus on normative analysis and field research. In the past three years, the literature accounts for $31.3 \%$ of the journals, and the empirical research methods also occupy a large weight, accounting for 25\%. The Western journal "Accounting, Organization and Society"/AOS is different from domestic journals. Western management accounting research methods focus more on experimental research, accounting for $36.4 \%$ of journals. And this experimental method is in a blank state in Accounting Research, Economic Research, and Management World. At the same time, the proportion of empirical research in AOS is not small, accounting for $27.3 \%$ of the journal.

\subsubsection{Distribution of Research Methods in Research Topics}

This paper further analyzes the application of research methods in various research topics. The results are shown in Table 4. As can be seen from Table 4, normative analysis/conceptual research methods are the most widely used in

Table 3. Distribution of research methods in different journals.

\begin{tabular}{cccccc}
\hline \multirow{2}{*}{ Research Methods } & $\begin{array}{c}\text { Accounting } \\
\text { Research }\end{array}$ & $\begin{array}{c}\text { Economic } \\
\text { Research }\end{array}$ & $\begin{array}{c}\text { Management } \\
\text { World }\end{array}$ & AOS & \\
\cline { 2 - 5 } & $\begin{array}{c}\text { Number Of } \\
\text { Articles (\%) }\end{array}$ & $\begin{array}{c}\text { Number Of } \\
\text { Articles (\%) }\end{array}$ & $\begin{array}{c}\text { Number Of } \\
\text { Articles (\%) }\end{array}$ & $\begin{array}{c}\text { Number Of } \\
\text { Articles (\%) }\end{array}$ & \\
\hline Empirical Research & $12(37.5)$ & $1(100.0)$ & $4(25.0)$ & $6(27.3)$ & $23(32.4)$ \\
Normative Analysis & $12(37.5)$ & $0(0.0)$ & $5(31.3)$ & $3(13.6)$ & $20(28.2)$ \\
Experimental Study & $0(0.0)$ & $0(0.0)$ & $0(0.0)$ & $8(36.4)$ & $8(11.3)$ \\
Field Research & $4(12.5)$ & $0(0.0)$ & $5(31.3)$ & $4(18.2)$ & $13(18.3)$ \\
Case Study & $3(9.4)$ & $0(0.0)$ & $0(0.0)$ & $1(4.5)$ & $4(5.6)$ \\
Analytical Model & $1(3.1)$ & $0(0.0)$ & $2(12.4)$ & $0(0.0)$ & $3(4.2)$ \\
Total & $32(100.0)$ & $1(100.0)$ & $16(100.0)$ & $22(100.0)$ & $71(100.0)$ \\
\hline
\end{tabular}

Note: The percentages in parentheses. 
Table 4. Distribution of research methods for different topics.

\begin{tabular}{|c|c|c|c|c|c|c|}
\hline \multirow{2}{*}{ Research Methods } & $\begin{array}{l}\text { Management } \\
\text { Control System }\end{array}$ & Cost & $\begin{array}{c}\text { Externally Oriented } \\
\text { Management Accounting }\end{array}$ & $\begin{array}{l}\text { Management Accounting } \\
\text { General Problem }\end{array}$ & Other Problems & \multirow{2}{*}{ Total } \\
\hline & $\begin{array}{l}\text { Number Of } \\
\text { Articles (\%) }\end{array}$ & $\begin{array}{l}\text { Number Of } \\
\text { Articles (\%) }\end{array}$ & Number Of Articles (\%) & Number Of Articles (\%) & $\begin{array}{c}\text { Number } \\
\text { Of Articles (\%) }\end{array}$ & \\
\hline Empirical Research & $14(36.8)$ & $5(71.4)$ & $3(30.0)$ & $1(8.3)$ & $0(0.0)$ & $23(32.4)$ \\
\hline Normative Analysis & $5(13.2)$ & $1(14.3)$ & $2(20.0)$ & $10(83.4)$ & $2(50.0)$ & $20(28.2)$ \\
\hline Experimental Study & $6(15.8)$ & $1(14.3)$ & $0(0.0)$ & $0(0.0)$ & $1(25.0)$ & $8(11.3)$ \\
\hline Field Research & $8(21.1)$ & $0(0.0)$ & $3(30.0)$ & $1(8.3)$ & $1(25.0)$ & $13(18.3)$ \\
\hline Case Study & $3(7.9)$ & $0(0.0)$ & $1(10.0)$ & $0(0.0)$ & $0(0.0)$ & $4(5.6)$ \\
\hline Analytical Model & $2(5.2)$ & $0(0.0)$ & $1(10.0)$ & $0(0.0)$ & $0(0.0)$ & $3(4.2)$ \\
\hline Total & $38(100.0)$ & $7(100.0)$ & $10(100.0)$ & $12(100.0)$ & $4(100.0)$ & $71(100.0)$ \\
\hline
\end{tabular}

Note: The percentages in parentheses.

various research topics, while case studies, analytical model studies, and experimental research are rarely used. Case studies and analytical model studies are only used in management control systems and management accounting general issues. Experimental research is mainly used in management control systems and cost accounting and management. From the research topic, the research methods of management and control systems are the most widely used, and all kinds of research methods are not only applied, but the proportion (except normative analysis) is the highest among all kinds of research methods. Normative analysis methods are mainly used in the general management accounting problems, mainly depending on the research nature of management accounting general issues, mainly focusing on the development and innovation of management accounting theory.

\section{Research Conclusions and Enlightenment}

\subsection{Research Conclusions}

This paper analyzes 71 management accounting research papers from 2015 to 2017, from several aspects such as the selection of management accounting papers, research topics of management accounting, and management accounting research methods. From the analysis results of this paper, the following four conclusions can be drawn:

Firstly, during the research period of the past three years, the research of management accounting has developed rapidly. In addition to the subject journal of management accounting research, Management World, other journals such as Accounting Research, there are more and more researches on management accounting. In addition, in the foreign TOP5 major journals, "Accounting, Organization and Society" (AOS) has contributed a lot to the research of management accounting in recent years.

Secondly, management control has always been the central issue of manage- 
ment accounting research, $53.5 \%$ of the 71 selected literatures have studied this issue. Among them, the evaluation of performance and measurement, as well as the study of compensation and incentives, have always been hot issues in management accounting research. At the same time, there have been many studies that have thought about and explored the development and integration of the management accounting control system itself. In addition, research on cost issues has paid more attention to the problem of enterprise cost stickiness in recent years, while traditional cost methods such as activity-based costing have been greatly reduced in recent years. With the greatness of supply chain research, the paper has established a sub-topic of externally oriented management accounting research with reference to previous studies. With the implementation of relevant national policies and opinions, management accounting research has been increasingly recognized by enterprises and the society. Therefore, there are many researches on the theory, conceptual framework and innovation of management accounting itself.

Thirdly, from the perspective of management accounting research methods in recent three years, different research methods have been widely used in different research topics. Because the problem of management control system is always the most important problem in the research of management accounting, the research method is the most extensive in this subject. The research methods of management accounting are viewed from the perspective of the differences between domestic and foreign journals, among which domestic journals, such as Accounting Research and Management World, use more data-based empirical research, normative research and field investigation research, and the experimental research is basically in a blank period. On the contrary, experimental research methods are more common in foreign literature, mainly used in the research of management control system and cost management. In addition, the methods of case study and model analysis are seldom used in the research of management accounting.

\subsection{Research Enlightenment}

To sum up the above-mentioned problems, we can get the following enlightenment from the problem, hoping to provide some reference for the development of management accounting.

1) Strengthen the Construction of the Theoretical System of Management Accounting

As the saying goes, the theoretical basis determines the height of practice, and the innovation and development of any discipline is inseparable from a complete theoretical system. Although the research theme of management accounting is closer to practical content, as an academic research, management accounting research should be theoretical. In comparison, nearly half of the domestic management accounting research has not found a clear theoretical source, and merely describes the concept of practice or management accounting, and has not 
risen to the theoretical level. In addition, in the theory of specific applications, domestic research is still based on economic theory, especially agency theory, and there are few management accounting studies in applied sociology and psychology. This paper believes that to implement the goal of forming a theoretical system of management accounting with Chinese characteristics, China's management accounting research should not be limited to "social practice" or "economic behavior", but should be combined with China's social and economic conditions and cultural background. Choose the right theory according to the research object and problem and even build a management accounting theory based on the Chinese background, and improve the theoretical, academic and international nature of management accounting research.

2) Construct Management Accounting Theory Based on Chinese Enterprise Practice

The research of management accounting should not only have academic value, but also should be close to and guide the management accounting practice of enterprises. As we all know, after the financial crisis broke out, China's economy has also been affected. How to survive or even gain competitive advantage in the context of financial crisis is a concern in corporate practice. Therefore, "reducing costs and increasing efficiency" has become the business target of many enterprises in the context of financial crisis. However, the statistical results of this paper show that there are not many studies on cost and control, etc., accounting for only $9.8 \%$ of the 71 articles. It is worth noting that there are many research topics about performance evaluation and compensation system, the availability of salary data and the particularity of salary management in Chinese enterprises are the main reasons why this kind of research has been widely concerned. However, this kind of research has limited help for enterprises to get rid of the impact of financial crisis and gain competitive advantage. It is imperative to discuss the influence of China's special political, economic, cultural and social environment on management accounting practice and theory from the perspective of Chinese traditional culture, customs, religion, human feelings, face and other informal systems as well as the interaction between formal and informal systems. Combining the elements of management accounting with Chinese characteristics with the existing theoretical framework of the west, this paper constructs the theoretical system of China's management accounting with the internal relationship between the institutionalization of management accounting and the knowledge system of management accounting as the main framework, in order to guide the practice of China's management accounting. In order to improve the international status of China's management accounting and make management accounting better guide the practice of enterprises, the future research of management accounting should be more close to the practice of enterprises, sort out and summarize China's management accounting tools and methods, refine the conceptual framework of management accounting, and gradually form a theoretical system of management accounting with Chinese characteristics. 


\section{3) Expand the Application of Experimental Research Methods}

At present, in the experimental research of management accounting in China, most of the topics are focused on budget and salary. Few scholars use behavioral experimental research method to study performance evaluation and cost control issues, which have been the focus of western experimental research of management accounting (Wang Ye, 2013) [23]. The narrow range of topics makes it difficult for the experimental research method to become the mainstream method of management accounting research in China as the questionnaire method. As can be seen from Table 3, the selected Chinese journals such as Accounting Research, Economic Research, and Management World have no literature on experimental research methods. The experimental research method can control some interference factors and ensure the validity of the experimental research, especially the establishment of causality in the research. The experimental research method has incomparable advantages. Therefore, the development of management accounting in China should expand the research topic of experimental research, so that experimental research method can be a good supplement in the research of management accounting.

\section{Conflicts of Interest}

The author declares no conflicts of interest regarding the publication of this paper.

\section{References}

[1] Shields, M.D. (1997) Research in Management Accounting by North Americans in the 1990s. Journal of Management Accounting Research, 9, 3-61.

[2] Du, R.R., Xiao, Z.Z. and Zhou, Q.W. (2009) Review of Management Accounting Research in China. Accounting Research, No. 9, 74-80.

[3] Meng, Y., Sun, J., et al. (2014) Review and Prospect of Management Accounting Research in China. Accounting Research, No. 9, 3-12.

[4] Zhou, B.C., Mark, W., Li, Z.Z., et al. (2016) EVA Model of Risk Adjustment and Its Application in Performance Evaluation of Central Enterprises. Management World, No. 6, 180-181.

[5] Chenhall, R.H., Hall, M. and Smith, D. (2017) The Expressive Role of Performance Measurement Systems: A Field Study of a Mental Health Development Project. Accounting, Organizations and Society, 63, 60-75. https://doi.org/10.1016/j.aos.2014.11.002

[6] Thornock, T.A. (2016) How the Timing of Performance Feedback Impacts Individual Performance. Accounting, Organizations and Society, 55, 1-11. https://doi.org/10.1016/j.aos.2016.09.002

[7] Abernethy, M.A., Bouwens, J. and Kroos, P. (2017) Organization Identity and Earnings Manipulation. Accounting, Organizations and Society, 58, 1-14. https://doi.org/10.1016/j.aos.2017.04.002

[8] Brown, J.L., Farrington, S. and Sprinkle, G.B. (2016) Biased Self-Assessments, Feedback, and Employees' Compensation Plan Choices. Accounting, Organizations and Society, 54, 45-59. https://doi.org/10.1016/j.aos.2016.08.003 
[9] Chai, C., Huang, S.Z. and Ye, Q.H. (2017) Competitive Strategy, Executive Compensation Incentive and Company Performance: Empirical Research Based on Three Compensation Incentive Perspectives. Accounting Research, No. 6, 45-53.

[10] Wang, X., Li, Y.L. and Li, F.S. (2015) Research on Corporate Social Responsibility and the Effectiveness of Managers' Compensation Incentive-Strategic Motivation or Excuse to Discharge Responsibility? Accounting Research, No. 10, 51-59.

[11] Arnold, M.C. and Gillenkirch, R.M. (2015) Using Negotiated Budgets for Planning and Performance Evaluation: An Experimental Study. Accounting, Organizations and Society, 43, 1-16. https://doi.org/10.1016/j.aos.2015.02.002

[12] Liu, L.B., Han, X.D. and Yang, F. (2015) Evolution and Significance Construction of Group Enterprise Budget Management Based on Vertical Case Study of Shenhua Group from 1998 to 2014. Accounting Research, No. 7, 42-49.

[13] Liu, L.B., Sun, Z. and Han, X.D. (2016) Budget Communication: Motivation, Form and Effect: Empirical Evidence Based on In-Depth Investigation of Chinese Enterprises. Accounting Research, No. 7, 81-89.

[14] Reusen, E. and Stouthuysen, K. (2017) Misaligned Control: The Role of Management Control System Imitation in Supply Chains. Accounting, Organizations and Society, 61, 22-35. https://doi.org/10.1016/j.aos.2017.08.001

[15] Chenhall, R.H. and Moers, F. (2015) The Role of Innovation in the Evolution of Management Accounting and Its Integration into Management Control. Accounting, Organizations and Society, 47, 1-13. https://doi.org/10.1016/j.aos.2015.10.002

[16] Bol, J.C., Kramer, S. and Maas, V.S. (2016) How Control System Design Affects Performance Evaluation Compression: The Role of Information Accuracy and Outcome Transparency. Accounting, Organizations and Society, 51, 64-73. https://doi.org/10.1016/j.aos.2016.01.001

[17] Jiang, W., Yao, W.T. and Hu, Y.M. (2016) The Implementation of the Minimum Wage Regulations and the Cost Stickiness of Enterprises. Accounting Research, No. $10,56-63$.

[18] Jia, J.F., Tang, G.Y., et al. (2015) The Impact of the Matching of Executive Competency and Strategic Orientation on Corporate Performance. Management World, No. 2, 120-132.

[19] Song, H. and Lu, Q. (2017) What Kind of SMEs Can Benefit from Supply Chain Finance? Based on the Perspective of Network and Capability. Management World, No. 6, 104-121.

[20] Shen, Y.F., Guo, X.M. and Lin, T. (2015) Background, Content and Impact of Cima Global Management Accounting Principles. Accounting Research, No. 10, 37-44.

[21] Feng, Q.G. (2015) Change Management and Innovation Exploration of Management Accounting. Accounting Research, No. 10, 30-37.

[22] Guan, R.D. and Nan, X.H. (2016) Innovation and Development of Management Accounting with Chinese Characteristics under the New Normal. Summary of 2016 Symposium of Management Accounting Professional Committee of Chinese Accounting Society. Accounting Research, No. 11, 92-94.

[23] Wang, Y. (2013) Application of Experimental Research Method in Foreign Management Accounting Research Based on Analysis of 73 Sample Literature Data. Journal of Nanjing Institute of Audit, No. 4, 69-77. 